\title{
Role of potash extract (Jar Kanwa) in suppression of male sexual desire: A study among Wister rats
}

\author{
Idris Sulaiman Abubakar, Ayyuba Rabiu \\ Department of Obstetrics and Gynecology, Bayero University Kano/Aminu Kano Teaching Hospital, Kano, Nigeria
}

\begin{abstract}
Consumption of potash extract is traditionally used for suppression of male sexual desire and as a fertility control method even before the emergence of modern contraceptives. This research was aimed at determining potash extract's role in suppression of male sexual desire. Four groups of virgin Wister rats were formed of which three groups were given different doses of potash extract and the fourth group as control. They were monitored for sexual desire with CCTV cameras and were sacrificed after 28 days. Serum testosterone and estrogen levels were assayed and sperm analysis was carried out. Data were analyzed using SPSS version 19 Statistical Software. A $p<0.05$ was considered as significant. Findings showed that higher doses of this potash extract (500 $\mathrm{mg} / \mathrm{kg}$ and $1,000 \mathrm{mg} / \mathrm{kg}$ ) stimulated more sexual desire, evidenced by increased duration of mounting. However, Serum testosterone and estrogen levels as proxy markers of sexual desire were found low in a dose dependent manner and with narrow margin of effects. The study showed no statistically significant difference between the control group and different treatment groups of potash extract on parameters of sperm analysis.
\end{abstract}

\section{Introduction}

Sexual desire is a motivational state in which individuals develop interest in sexual objects or activities, or as a wish, or drive to seek out sexual objects or to engage in sexual activities. ${ }^{1}$

Correspondence: Ayyuba Rabiu, Department of Obstetrics and Gynecology, Bayero University Kano/Aminu Kano Teaching Hospital, P.M.B. 3011, Nigeria.

Tel.: 08055559473.

E-mail: ayyubarabiu@yahoo.com

Key words: Potash Extract, Sexual Desire, Suppression, Wister rats.

Contributions: The authors contributed equally.

Conflict of interest: The authors declare no potential conflict of interest.

Funding: None.

Received for publication: 5 July 2019.

Revision received: 12 February 2020.

Accepted for publication: 12 February 2020.

This work is licensed under a Creative Commons Attribution NonCommercial 4.0 License (CC BY-NC 4.0).

CC Copyright: the Author(s), 2019

Licensee PAGEPress, Italy

Annals of African Medical Research 2019; 2:81

doi:10.4081/aamr.2019.81
It is synonymous with Libido, lust, sexual drive, desire, sexual interest or sexual urge. ${ }^{2}$ It is largely unconscious and low sexual derive can influence the chance of conception and fertility for obvious reasons. Sexual desire is being addressed differently based on culture, religion and tradition. In the monk's practice, sexual desires are tackled by being modest in dressing and fasting which are believed to make a monk develop a healthy self-discipline. ${ }^{3}$ In Europe and America, their Western culture, which permits total acceptance of sexual and reproductive rights, sexual desire is never considered as a challenge and has little or no role in fertility control, family planning and other effects of unwanted pregnancy and its complications.

In Africa, particularly in Northern Nigeria, where majority are of Islamic faith, there is no room for sexual intercourse outside marriage and the only option for the unmarried is abstinence, as such, any available remedy that will reduce sexual desire will invariably play a greater role towards complying with religious injunction and tradition.

One of those remedies which locals believe reduces sexual desire, is the consumption of yellowish white crystal potash, a naturally occurring mineral salt called Jar Kanwa in Hausa language. It is believed to suppress sexual desire in men and provides contraception in women. Consumption of this yellowish-white Crystal Potash for suppression of excessive sexual desire has been known in sub Saharan Africa since antiquity. Anecdotal evidence from Northern Nigeria has confirmed that adolescents, young adults and long distant drivers consume potash with the assumption it suppresses sexual desire and destroys sperm cells accumulated in the male gonads.

Suppression of male sexual desire will invariably play a greater role in achieving sexual and reproductive health. If male adolescents are provided with an option for suppression of sexual desire, issues like peer influence, falling societal norms and values will be remarkably improved to the extent of avoiding teenage pregnancy and its consequences such as school dropouts, sexual promiscuity, a greater number of children, maternal and perinatal death, reproductive health risks and unsafe abortion. In another perspective, suppression of sexual desire is like an addendum on the practice of abstinence. Therefore, complications such as sexually transmitted infections including Human immunodeficiency virus/acquired immune deficiency syndrome (HIV/AIDS) will be curtailed to the minimum.

This research was aimed at determining the effect of potash on male sexual desire among male Wister rats.

\section{Materials and Methods}

This research was conducted in the pharmacology laboratory of Bayero University Kano and Ahmadu Bello University Zaria from $1^{\text {st }}$ June, 2018 to $31^{\text {st }}$ October, 2018. Approval for the research was obtained from The College of Health Sciences, Bayero University, Kano (BUK/CHS/REC/VI/56).

A pure potash extract was collected from Haji Bukaran, an area 
of Nguru Local Government area of Yobe State. The collected pure sample of potash was grinded to a powdered state using pestle and mortar. A sample or powdered potash $(3 \mathrm{~kg})$ was dissolved in 2 liters of distilled water. The solvent was filtered using No 1 Whatmann's filter paper, size 12.5 microm and allowed to dry in desiccators at $45^{\circ} \mathrm{C}$. The process was repeated until adequate potash extract was obtained.

Adults Wister rats were purchased from the animal house of Ahmadu Bello University (ABU) Zaria with a weight of 110-130g each. The rats were kept at the animal house of pharmacology department of Bayero University Kano (BUK) under normal laboratory conditions. They were allowed unrestricted access to standard feed (Vital feed growers) obtainable from Brand Cereals and Oil Mills Ltd, Bukuru, Jos, Nigeria and water ad libitum throughout the experimental period. They were handled in accordance with the guidelines for the care and use of laboratory animals. The animals were randomly selected and marked to allow individual identification and kept in their cages for five days prior to the experiment to allow for acclimatization to the laboratory conditions. Acute toxicity (LD50) study of the potash extract was carried out using the method described by Lorke. ${ }^{4}$ Based on the result of LD50; four groups of Wister rats; Group I, II, III and IV, each containing six males and three females were formed. Group I was administered distilled water while group II were administered $20 \%$ $(1,000 \mathrm{mg} / \mathrm{kg})$ of the highest non-lethal dose. Group III and IV were administered $10 \%(500 \mathrm{mg} / \mathrm{kg})$ and $5 \%(250 \mathrm{mg} / \mathrm{kg})$ of the highest non-lethal dose respectively. These were done continuously for 28 days. Intakes of food and water were recorded daily while weights of animals were recorded weekly. The male and female Wister rats were only brought together in the same cage on the evening of days $0,7,14,21$ and 28 and separated after 12 hours throughout the period of 28 days and were kept under surveillance for sexual activities with the use of closed-circuit television (CCTV) cameras (Figures 1 and 2). After a period of 28 days; the animals were starved overnight, administered chloroform and humanely sacrificed. Top view conventional CCTV cameras were mounted one above each cage of the Wister rats. This allowed the principal investigator to manually inspect and score recorded mounting behaviors (frequency and duration) as proxy markers of sexual desire based on the modification of procedures done by other researchers. ${ }^{5-7}$ The recording was done for a period of 12 hours in the selected days starting from $6.00 \mathrm{pm}$. In this study, female Wister rats were only allowed to stay in the same cages with male Wister rats at the time of CCTV recording and immediately separated the next day after recording. The male and female Wister rats were also considered virgin for they did not have any sexual exposure prior to the study. The recording was also done under red light illumination which is considered dark for rats. ${ }^{8}$ This is because rats are nocturnal animals and white light disrupts their circadian cycle. Blood samples were collected from the jugular vein of each male rat in SST (serum separating tube) bottles containing silica particles and a serum separating gel for hormonal assay (testosterone and estrogen) following chloroform anesthesia. They were properly labeled to allow easy identification. The blood samples were then conveyed to the appropriate laboratory unit and were centrifuged and the sera of samples were separated at 3000 RPM enabled for 10 minutes. The concentrations of testosterone and estrogen of sera specimens were measured by ELISA kits. The semen of the male Wister rats was also collected from the cauda epididymis in plain containers properly labeled for seminal fluid analysis. The concentration of spermatozoa in the epididymis of the Wister rats was analyzed by means of a micro puncture technique. ${ }^{9}$ In this study, the left epididymis was collected from all the sacrificed male Wister rats. The sperm was then released by cutting the cauda epididymidis longitudinally with a pair of fine-pointed scissors and compressing with forceps. The sperm was deposited free of epididymal tissue into the cavity.

The results were collected in pictures and tabular forms. Parametric data were analyzed using one-way ANOVA, and Dunnett's post hoc test while non-parametric data were analyzed using Kruskal-Wallis Test and Mann Whitney Test with SPSS Version 19 statistical software (IBM SPSS Inc., IL, Chicago, USA). A p-value of $<0.05$ was considered as significant.

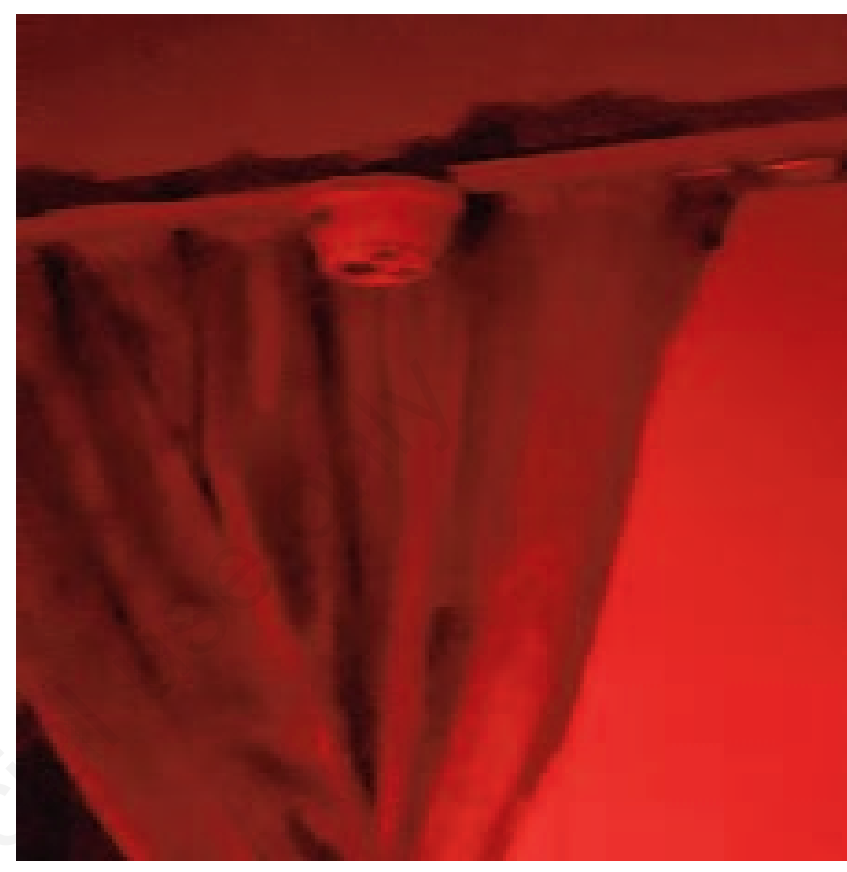

Figure 1. Mounted Top CCTV Camera under Red Light.

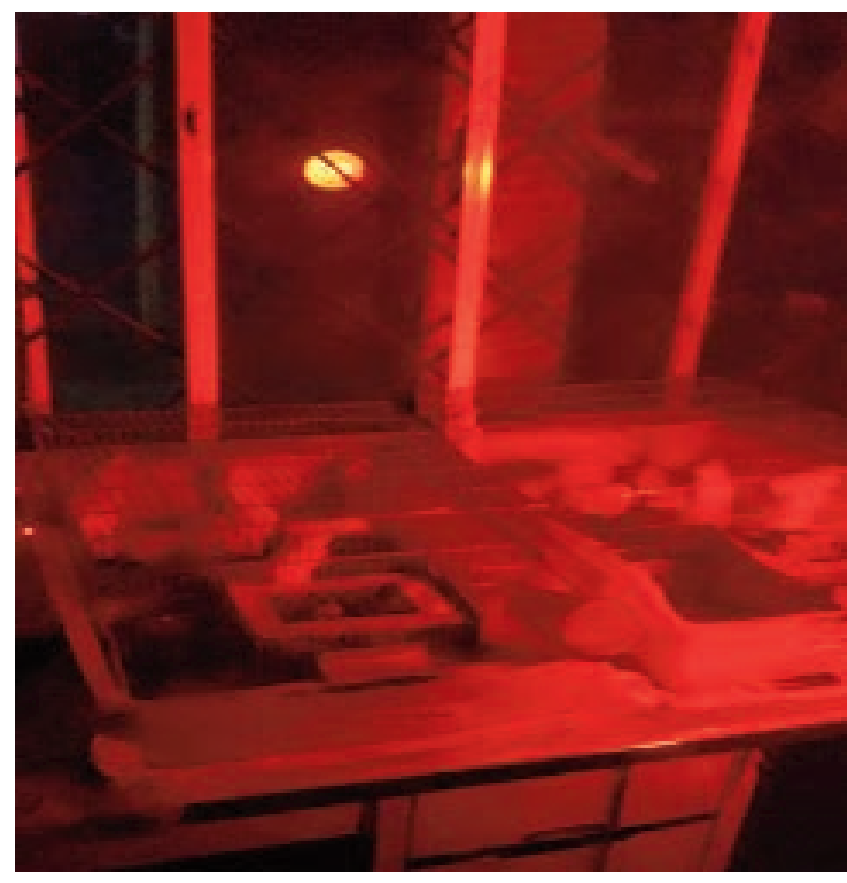

Figure 2. Caged Wister Rats under CCTV Camera with Red Light. 


\section{Results}

Group II, III and IV of the Wister rats were given 1,000 mg, $500 \mathrm{mg}$ and $250 \mathrm{mg}$ of potash extract daily over a period of 28 days while group 1 (control) was on food and water only.

There was a significant effect of potash extract on the duration of mounting at the $\mathrm{p}<0.05$ level of the four different doses $[\mathrm{F}(3,12)=4.895, \mathrm{p}=0.019]$ (Table 1$)$.

Post hoc comparisons using the Dunnett test indicated that the mean score for the control $(\mathrm{M}=2.12 \mathrm{SD}=0.14)$ was significantly different than the $1,000 \mathrm{mg} / \mathrm{kg}(\mathrm{M}=2.55, \mathrm{SD}=0.16)$ and the 500 $\mathrm{mg} / \mathrm{kg} \quad(\mathrm{M}=2.51, \mathrm{SD}=0.26)$. However, the $250 \mathrm{mg} / \mathrm{kg}$ group $(\mathrm{M}=2.24, \mathrm{SD}=0.16)$ did not differ significantly from the control group. Taken together, these results suggest that high levels of potash extract really do have an effect of prolonging the duration of mounting. The direction of the effect was towards the highest dose $(1,000 \mathrm{mg} / \mathrm{kg})$ (Table 1).

There was no significant effect of potash extract on the nonmotility of the sperm cells at the $\mathrm{p}<0.05$ level of the four different doses $[F(3,18)=0.983, p=0.423]$.

There was no significant effect of potash extract on the number of viable sperm cells at the $\mathrm{p}<0.05$ level of the four different doses $[\mathrm{F}(3,18)=3.110, \mathrm{p}=0.052]$ (Table 2).

There was no significant effect of potash extract on the number of non-viable sperm cells at the $\mathrm{p}<0.05$ level of the four different doses $[\mathrm{F}(3,18)=3.110, \mathrm{p}=0.052]$.

Table 1. Duration of mounting (per second).

\begin{tabular}{|c|c|c|c|c|c|c|c|c|c|c|}
\hline \multirow[t]{3}{*}{ Variables } & \multirow[t]{3}{*}{ N. } & \multirow[t]{3}{*}{ Mean } & \multirow[t]{3}{*}{ SD } & \multirow[t]{3}{*}{ SEM } & \multirow{2}{*}{\multicolumn{2}{|c|}{$95 \%$ CI for Mean }} & \multicolumn{4}{|c|}{$\begin{array}{l}\text { Post hoc comparisons using the Dunnett test } \\
\text { on duration of mounting }\end{array}$} \\
\hline & & & & & & & Mean Difference (I-J) & Sig. & & \\
\hline & & & & & Lower Bound & Upper Bound & & & Lower Bound & Upper Bound \\
\hline Control & 4 & 2.13 & 0.14 & 0.07 & 1.90 & 2.35 & & & & \\
\hline $1,000 \mathrm{mg} / \mathrm{kg}$ & 4 & 2.55 & 0.20 & 0.08 & 2.29 & 2.80 & $0.43^{*}$ & 0.018 & 0.07 & 0.78 \\
\hline $500 \mathrm{mg} / \mathrm{kg}$ & 4 & 2.51 & 0.26 & 0.13 & 2.10 & 2.91 & $0.38 *$ & 0.033 & 0.03 & 0.73 \\
\hline $250 \mathrm{mg} / \mathrm{kg}$ & 4 & 2.24 & 0.16 & 0.08 & 1.98 & 2.50 & 0.12 & 0.693 & -0.23 & 0.47 \\
\hline Total & 16 & 2.35 & 0.25 & 0.06 & 2.22 & 2.49 & +2 & & & \\
\hline
\end{tabular}

$\mathrm{N}=$ Number of weeks, $\mathrm{SD}=$ standard deviation, $\mathrm{SEM}=$ standard error of the mean, $\mathrm{Cl}=$ confidence interval, Sig=significance.

Table 2. Sperm parameters.

\begin{tabular}{|c|c|c|c|c|c|c|}
\hline \multirow[t]{2}{*}{ Variables } & \multirow[t]{2}{*}{$\mathbf{N}$} & \multirow[t]{2}{*}{ Mean } & \multirow[t]{2}{*}{ SD } & \multirow[t]{2}{*}{ SEM } & \multicolumn{2}{|c|}{$95 \%$ CI for Mean } \\
\hline & & & & & Lower Bound & Upper Bound \\
\hline \multicolumn{7}{|c|}{ Non-Motile Cells } \\
\hline Control & 6 & 23.50 & 23.54 & 9.61 & -1.20 & 48.20 \\
\hline $1,000 \mathrm{mg} / \mathrm{kg}$ & 4 & 22.25 & 12.66 & 6.33 & 2.11 & 42.39 \\
\hline $500 \mathrm{mg} / \mathrm{kg}$ & 6 & 23.17 & 13.59 & 5.55 & 8.91 & 37.42 \\
\hline 250 mg/kg & 6 & 37.33 & 15.98 & 6.53 & 20.56 & 54.11 \\
\hline Total & 22 & 26.95 & 17.38 & 3.71 & 19.25 & 34.66 \\
\hline \multicolumn{7}{|c|}{ Viable Cells } \\
\hline Control & 6 & 68.00 & 7.64 & 3.12 & 59.98 & 76.02 \\
\hline $1,000 \mathrm{mg} / \mathrm{kg}$ & 4 & 65.25 & 11.44 & 5.72 & 47.04 & 83.46 \\
\hline $500 \mathrm{mg} / \mathrm{kg}$ & 6 & 58.83 & 7.33 & 2.99 & 51.14 & 66.53 \\
\hline $250 \mathrm{mg} / \mathrm{kg}$ & 6 & 53.67 & 9.26 & 3.78 & 43.94 & 63.39 \\
\hline Total & 22 & 61.09 & 10.00 & 2.13 & 56.66 & 65.52 \\
\hline \multicolumn{7}{|c|}{ Non-Viable Cells } \\
\hline Control & 6 & 32.00 & 7.64 & 3.12 & 23.98 & 40.02 \\
\hline $1,000 \mathrm{mg} / \mathrm{kg}$ & 4 & 34.75 & 11.44 & 5.72 & 16.54 & 52.96 \\
\hline $500 \mathrm{mg} / \mathrm{kg}$ & 6 & 41.17 & 7.33 & 3.10 & 33.47 & 48.86 \\
\hline $250 \mathrm{mg} / \mathrm{kg}$ & 6 & 46.33 & 9.27 & 3.79 & 36.61 & 56.06 \\
\hline Total & 22 & 38.91 & 10.00 & 2.13 & 34.48 & 43.34 \\
\hline \multicolumn{7}{|c|}{ Total Sperm Cells Count } \\
\hline Control & 6 & 31.33 & 13.81 & 5.64 & 16.85 & 45.82 \\
\hline 1,000 mg/kg & 4 & 25.05 & 6.67 & 3.33 & 14.44 & 35.66 \\
\hline $500 \mathrm{mg} / \mathrm{kg}$ & 6 & 33.63 & 12.40 & 5.06 & 20.63 & 46.64 \\
\hline $250 \mathrm{mg} / \mathrm{kg}$ & 6 & 25.99 & 11.59 & 4.73 & 13.82 & 38.14 \\
\hline Total & 22 & 29.36 & 11.55 & 2.46 & 24.24 & 34.48 \\
\hline
\end{tabular}

$\mathrm{N}=$ number of rats in the groups. 
There was no statistically significant effect of potash extract on the total sperm cells count at the $\mathrm{p}<0.05$ level of the four different doses $[\mathrm{F}(3,18)=0.655, \mathrm{p}=0.590]$ (Table 2).

There was statistically significant effect of potash extract on the total number of head defect at the $\mathrm{p}<0.05$ level of the four different doses $[F(3,18)=4.678, p=0.014]$ (Table 3).

Post hoc comparisons using the Dunnett test indicated that the mean score for the control $(\mathrm{M}=34.67, \mathrm{SD}=5.43)$ was significantly different than the $500 \mathrm{mg} / \mathrm{kg}(\mathrm{M}=20.83, \mathrm{SD}=5.27)$. These results suggest that moderate levels of potash extract $(500 \mathrm{mg} / \mathrm{kg})$ really do have an effect on the sperms' head defects (reduced the number of sperms with head defects) (Table 3).

There was statistically significant effect of potash extract on the serum testosterone level at the $\mathrm{p}<0.05$ level of the four different doses $[F(3,18)=12.947, \mathrm{p}=0.000]$ (Table 4).

Post hoc comparisons using the Dunnett test indicated that the mean score for the control $(\mathrm{M}=1.77, \mathrm{SD}=0.21)$ was significantly different than the $500 \mathrm{mg} / \mathrm{kg}(\mathrm{M}=1.19, \mathrm{SD}=0.26)$ and the 250 $\mathrm{mg} / \mathrm{kg}(\mathrm{M}=0.83, \mathrm{SD}=0.39)$. These results suggest that moderate and low levels of potash extract really do have an effect of reducing serum level of testosterone.

A Kruskal-Wallis $\mathrm{H}$ test showed that there was no statistically significant difference in the number of mounting between the different potash extract treatments $\chi^{2}(3)=2.760, p=0.430$, with a mean rank of 5.50 for control, 10.00 for $1,000 \mathrm{mg} / \mathrm{kg}, 10.50$ for 500 $\mathrm{mg} / \mathrm{kg}$ and 8.00 for $250 \mathrm{mg} / \mathrm{kg}$ doses of the potash.

A Kruskal-Wallis $\mathrm{H}$ test showed that there was no statistically significant difference in the number of active cells between the different potash extract treatments $\chi^{2}(3)=6.836, \mathrm{p}=0.077$, with a mean rank of 12.83 for control, 14.13 for $1,000 \mathrm{mg} / \mathrm{kg}, 14.25$ for $500 \mathrm{mg} / \mathrm{kg}$ and 5.67 for $250 \mathrm{mg} / \mathrm{kg}$ doses of the potash.

A Kruskal-Wallis $\mathrm{H}$ test showed that there was no statistically significant difference in the number of sluggish cells between the different potash extract treatments $\chi^{2}(3)=2.382, \mathrm{p}=0.497$, with a mean rank of 10.08 for control, 9.38 for $1,000 \mathrm{mg} / \mathrm{kg}, 11.00$ for $500 \mathrm{mg} / \mathrm{kg}$ and 14.83 for $250 \mathrm{mg} / \mathrm{kg}$ doses of the potash.

A Kruskal-Wallis $\mathrm{H}$ test showed that there was no statistically significant difference in the number of sperm tail defects between the different potash extract treatments $\chi^{2}(3)=0.289, \mathrm{p}=0.962$, with a mean rank of 10.50 for control, 11.50 for $1,000 \mathrm{mg} / \mathrm{kg}, 11.50$ for $500 \mathrm{mg} / \mathrm{kg}$ and 12.50 for $250 \mathrm{mg} / \mathrm{kg}$ doses of the potash.

A Kruskal-Wallis $\mathrm{H}$ test showed that there was no statistically significant difference in the normal sperm cell morphology between the different potash extract treatments $\chi^{2}(3)=$ 6.316, $\mathrm{P}=0.097$, with a mean rank of 8.50 for control, 9.88 for $1,000 \mathrm{mg} / \mathrm{kg}, 17.08$ for $500 \mathrm{mg} / \mathrm{kg}$ and 10.00 for $250 \mathrm{mg} / \mathrm{kg}$ doses of the potash.

A Kruskal-Wallis $\mathrm{H}$ test showed that there was a statistically significant difference in the serum level of estrogen between the different potash extract treatments $\chi^{2}(3)=8.957, \mathrm{p}=0.030$, with a mean rank of 16.58 for control, 8.00 for $1,000 \mathrm{mg} / \mathrm{kg}, 13.67$ for $500 \mathrm{mg} / \mathrm{kg}$ and 6.58 for $250 \mathrm{mg} / \mathrm{kg}$ doses of the potash.

Mean rank in control and $1,000 \mathrm{mg} / \mathrm{kg}$ groups were 7.00 and 3.25; the distributions in the two groups did not differ significantly (Mann-Whitney $\mathrm{U}=3.00, \mathrm{n} 1=6, \mathrm{n} 2=4, \mathrm{p}=0.55$ two-tailed)."

Mean rank in control and $500 \mathrm{mg} / \mathrm{kg}$ groups were 7.50 and 5.50; the distributions in the two groups did not differ significantly (Mann-Whitney $\mathrm{U}=12.00, \mathrm{n} 1=\mathrm{n} 2=6, \mathrm{p}=0.336$ two-tailed)."

Mean rank in control and $250 \mathrm{mg} / \mathrm{kg}$ groups were 9.08 and 3.92; the distributions in the two groups differed significantly (Mann-Whitney $\mathrm{U}=2.500, \mathrm{n} 1=\mathrm{n} 2=6, \mathrm{p}=0.013$ two-tailed)."

Therefore, the difference was between the control and the 250 $\mathrm{mg} / \mathrm{kg}$ groups. Potash extract reduces serum estrogen at of Wister rats at a dose of $250 \mathrm{mg} / \mathrm{kg}$.

Table 3. Sperm head defect.

\begin{tabular}{|c|c|c|c|c|c|c|c|c|c|c|}
\hline \multirow[t]{2}{*}{ Variables } & \multirow[t]{2}{*}{ N. } & \multirow[t]{2}{*}{ Mean } & \multirow[t]{2}{*}{ SD } & \multirow[t]{2}{*}{ SEM } & \multicolumn{2}{|c|}{ 95\% CI for Mean } & \multicolumn{4}{|c|}{$\begin{array}{l}\text { Post hoc comparisons using the Dunnett test } \\
\text { on duration of mounting }\end{array}$} \\
\hline & & & & & Lower Bound & Upper Bound & Mean Difference (I-J) & Sig. & $\begin{array}{r}95 \% \\
\text { Lower Bound }\end{array}$ & Upper Bound \\
\hline Control & 6 & 34.67 & 5.43 & 2.22 & 28.97 & 40.36 & & & & \\
\hline $1,000 \mathrm{mg} / \mathrm{kg}$ & 4 & 28.00 & 9.42 & 4.71 & 13.02 & 42.98 & -6.67 & 0.29 & -17.38 & 4.04 \\
\hline $500 \mathrm{mg} / \mathrm{kg}$ & 6 & 20.83 & 5.27 & 2.15 & 15.30 & 26.36 & $-13.83^{*}$ & 0.00 & -23.41 & -4.25 \\
\hline $250 \mathrm{mg} / \mathrm{kg}$ & 6 & 29.33 & 6.28 & 2.57 & 22.74 & 35.93 & -5.33 & 0.37 & -14.91 & 4.25 \\
\hline Total & 22 & 28.23 & 7.97 & 1.70 & 24.69 & 31.76 & & & & \\
\hline
\end{tabular}

$\mathrm{N}=$ number of rats in the groups.

Table 4. Serum testosterone level.

\begin{tabular}{|c|c|c|c|c|c|c|c|c|c|c|}
\hline \multirow[t]{3}{*}{ Variables } & \multirow[t]{3}{*}{ N. } & \multirow[t]{3}{*}{ Mean } & \multirow[t]{3}{*}{ SD } & \multirow[t]{3}{*}{ SEM } & \multicolumn{2}{|c|}{$95 \%$ CI for Mean } & \multicolumn{4}{|c|}{$\begin{array}{l}\text { Post hoc comparisons using the Dunnett test } \\
\text { on duration of mounting }\end{array}$} \\
\hline & & & & & \multirow[b]{2}{*}{ Lower Bound } & \multirow[b]{2}{*}{ Upper Bound } & \multirow[t]{2}{*}{ Mean Difference (I-J) } & \multirow[t]{2}{*}{ Sig. } & \multicolumn{2}{|c|}{$95 \%$ CI } \\
\hline & & & & & & & & & Lower Bound & Upper Bound \\
\hline Control & 6 & 1.77 & 0.21 & 0.09 & 1.55 & 1.99 & & & & \\
\hline $1,000 \mathrm{mg} / \mathrm{kg}$ & 4 & 1.83 & 0.36 & 0.18 & 1.26 & 2.39 & 0.06 & 0.99 & -0.46 & 0.57 \\
\hline $500 \mathrm{mg} / \mathrm{kg}$ & 6 & 1.19 & 0.26 & 0.11 & 0.91 & 1.46 & $-0.58^{*}$ & 0.01 & -1.04 & -0.12 \\
\hline $250 \mathrm{mg} / \mathrm{kg}$ & 6 & 0.83 & 0.39 & 0.16 & 0.41 & 1.25 & $-0.94^{*}$ & 0.00 & -1.40 & -0.48 \\
\hline Total & 22 & 1.36 & 0.51 & 0.11 & 1.14 & 1.59 & & & & \\
\hline
\end{tabular}

$\mathrm{N}=$ number of rats in the groups 


\section{Discussion}

We found significant effects of the potash extract on the duration of mounting, a proxy marker of sexual desire, and most importantly, the effect was so remarkable on the Wister rats with the two highest doses of potash extract $(1,000 \mathrm{mg} / \mathrm{kg}$ and $500 \mathrm{mg} / \mathrm{kg})$. This was shown following one-way ANOVA $(p<0.05)$ and Post Hoc Comparisons using the Dunnetts test $[\mathrm{p}<0.05$ for $1,000 \mathrm{mg} / \mathrm{kg}$ and $500 \mathrm{mg} / \mathrm{kg}$ of potash extract]. This indicates higher doses of potash extract stimulate sexual behavior while lower doses have no effect. The extract has rather stimulatory effect towards excessive sexual desire instead of lowering libido at higher doses. In term of number of mounting, the difference was not statistically significant between different potash extract treatments $(p>0.050)$. This finding is dissimilar to the aphrodisiac activity of hydro-alcoholic extract of the fruits of Cydonia oblonga when administered to Wister rats orally at doses of $500 \mathrm{mg} / \mathrm{kg}$ and $800 \mathrm{mg} / \mathrm{kg}$ per day as a single dose for 28 days which showed that after administration of the extract, mounting frequency and the mating performance of the rats increased highly significantly $(\mathrm{p}<0.01) .{ }^{10}$

The results showed that active sperm cells, sluggish sperm cells, non-motile cells, number of viable cells, tail defects, total sperm count, and normal sperm cell morphology were not significantly different between the different potash extract treatment groups and the control group $(\mathrm{p}<0.05)$. A study conducted on assessment of sperm production and reproductive organs of Wister rats to long-term exposure of Caesalpinia ferrea, a medicinal plant used to treat diabetes, showed that Sperm concentrations from the secretion of the right epididymis cauda were normal when compared with the control and there were no significant differences between the mean values of the two groups; the proportion of normal and abnormal spermatozoa of control and treated groups were equal. ${ }^{11}$ Our findings were similar. The most common abnormality that was statistically associated with exposure to the potash extract in our study was sperm cell with Head defect which was notably reduced among the $500 \mathrm{mg} / \mathrm{kg}$ group when compared to the control group. Presence of head defects was statistically significant between the control group and the $500 \mathrm{mg} / \mathrm{kg}$ treatment group $(p<0.05)$. Here, there were more head defects in the control group than in the treatment group of $500 \mathrm{mg} / \mathrm{kg}$ and the difference between the two groups was statistically significant $(p=0.00)$. Similar abnormalities were reported in the study of long-term exposure of Caesalpinia ferrea to Wister rats. ${ }^{11}$ The study has shown that active sperm cells, number of viable cells, total sperm count and normal sperm morphology are generally unaffected by consumption of the potash extract. Therefore, the popular belief that potash extract destroys sperm cells accumulated in the male gonads should be disregarded until human trial is carried out, with contrary findings.

Findings from this study showed that $250 \mathrm{mg} / \mathrm{kg}$ and 500 $\mathrm{mg} / \mathrm{kg}$ of the potash extract reduced serum testosterone of the exposed Wister rats and the reduction was statistically significant $(\mathrm{p}<0.05)$. However, there was no effect on the $1000 \mathrm{mg} / \mathrm{kg}$ group. An analysis with Post Hoc comparisons using Dunnett test on the serum testosterone showed that the control group was significantly different with the $500 \mathrm{mg} / \mathrm{kg}$ group $(\mathrm{p}=0.01)$ and $250 \mathrm{mg} / \mathrm{kg}$ $(p=0.00)$. This showed that the effect of low serum testosterone based on exposure to potash extract was dose dependent with a narrow margin of effectiveness. At a dose of $250 \mathrm{mg} / \mathrm{kg}$ to 500 $\mathrm{mg} / \mathrm{kg}$ there was a reduction of serum testosterone but increasing the dose to $1000 \mathrm{mg} / \mathrm{kg}$, the effect (reduction in serum testosterone) was lost. What this study failed to demonstrate is whether the reduction of serum testosterone was in all the exposed groups of the Wister rats with different severity that was affected by neg- ative feedback mechanisms. This could mean the $1000 \mathrm{mg} / \mathrm{kg}$ group was initially affected resulting in low serum testosterone but became resistant and recovered fully following chronic exposure with a relatively higher dose. However, blood sample was only taken after 28 days not serially and as such, the effect of low serum testosterone was abated at the time the animals were sacrificed. A clear picture of this dilemma could only be revealed if at every week during the study period, certain number of Wister rats would be sacrificed, theirs blood sample taken and analyzed for serum testosterone. A study on the effects of garlic (Allium sativum L.) hydro-alcoholic extract on estrogen, progesterone and testosterone levels in rats exposed to cell phone radiation showed that male mean serum levels of testosterone in the experimental groups revealed a significant decrease compared to control $(\mathrm{p}<0.01) .{ }^{12}$

In the case of serum estrogen, the study showed that only the $250 \mathrm{mg} / \mathrm{kg}$ group was statistically different from the control group (Mann-Whitney $\mathrm{U}=2.500, \mathrm{n} 1=\mathrm{n} 2=6, \mathrm{P}=0.013$ two-tailed). The $500 \mathrm{mg} / \mathrm{kg}$ and the $1000 \mathrm{mg} / \mathrm{kg}$ groups were not statistically different from the control group ( $\mathrm{p}>0.05)$. Therefore, the difference was between the control and the $250 \mathrm{mg} / \mathrm{kg}$ groups. This showed that only small amount of potash extract was required to lower serum estrogen and increasing the dose of the potash had no effect of lowering serum estrogen. Similar hypothesis on the effect of testosterone and the feedback mechanism could be explained too. Our finding was contrary to the effects of garlic (Allium sativum L.) hydro-alcoholic extract on estrogen where mean serum levels of estrogen in the sham group and experimental groups 1, 2 and 3 showed a significant decrease compared to control $(\mathrm{p}<0.005) .{ }^{12}$

As part of the Limitations in this study, side view cameras were not used in monitoring the sexual behavior as such intromission, latency, frequency, ejaculation, male licking of the genitalia after intromission or ejaculation were not monitored, contrary to other studies. ${ }^{13,14}$ Also, total serum testosterone level was measured quantitatively instead of free testosterone due to difficulty in obtaining specific kits for rat's free testosterone.

\section{Conclusions}

The study showed no statistically significant difference between the control group and different treatment groups of potash extract on parameters of sperm analysis and the potash extract was found to lower serum testosterone and estrogen levels in a dose dependent manner and with narrow margin of effects which invariably showed its effect of reducing sexual desire among experimental animals.

\section{Recommendations}

Consumption of potash extract has no effect in lowering sexual desire. It only lowers serum testosterone and estrogen levels in a dose dependent manner. Research should be focused on new drugs that can ultimately reduce sexual desire and fertility.

\section{References}

1. Regan P, Atkins L. Sex Differences and Similarities in Frequency and Intensity of Sexual Desire. Soc Behav Personal 2006;34:95-102.

2. Rowland D. The Enigma of Sexual Desire, Part 1: A Brief Review of Classical, Historical, Philosophical, and Literary Perspectives. Curr Sex Heal Reports 2016;8:158-62.

3. Sexual Desire, by The Dalai Lama. 2014; Available from: https://buddhismnow.com/2014/03/21/sexual-desire-by-the- 
dalai-lama/. Accessed on 02/10/2019.

4. Lorke D. A new approach to practical acute toxicity testing. Arch Toxicol 1983;54:275-87.

5. Dewsbury D, Daris H. Effects of reserpine on the copulatory behaviour of male rats. Physio Behav 1970;5:1331-533.

6. Szechtman H, Simantov R, Hershkowitz M. Sexual behaviours decreases pain sensitivity and stimulates endogenous opioids in male rats. Eur J Pharm 1981;70:278-86.

7. Amin K, Rahman S, Khan N. Sexual function improving effect of Mucuna pruriens in sexually normal male rats. Fitoterapia 1996;67:53-8.

8. Hong W, Kennedy A, Burgos-Artizzu X, et al. Automated measurement of mouse social behaviors using depth sensing, video tracking, and machine learning. Proc Natl Acad Sci 2015;112:E5351-60.

9. Turner T, Hartmann P, Howards S. In vivo sodium, potassium and sperm concentrations in the rat epididymis. Fertil Steril
1977;28:191-4.

10. Aslam M, Sial A. Effect of hydroalcoholic extract of cydonia oblonga miller (Quince) on sexual behaviour of wistar rats. Adv Pharmacol Sci 2014;2014:1-6.

11. Lucinda L, Rocha C, Reboredo M. Assessment of sperm production and reproductive organs of Wistar rats to long-term exposure of Caesalpinia ferrea. Ann Brazilian Acad Sci 2010; 82:907-14.

12. Hajiuon B. Effects of Garlic (Allium sativum L.) Zahedan J Res Med Sci 2014;16:20-5.

13. Hassan A, Hassouna M, Taketo T, et al The effect of diabetes on sexual behavior and reproductive tract function in male rats. J Urol 1993;149:148-54.

14. Tong Y, Hungb Y, Lina S, Chengh J. Dark-Cycle Video Surveillance of Sexual Performances of Normal and Diabetic Rats. Urol Intemational 1996;56:207-10. 